\section{NEW DISTRIBUTION RECORD OF THE ENDEMIC AND RARE FICUS DALHOUSIAE MIQ. (MORACEAE)}

K.K. Sampath Kumara ${ }^{1}$, A.N. Sringeswara ${ }^{2}$, K.B. Sadananda ${ }^{3}$ \& H.S. Prakash ${ }^{4}$

${ }^{1,4}$ Department of Studies in Biotechnology, University of Mysore, Manasagangotri, Mysuru, Karnataka 570006, India

${ }^{2}$ Department of Forestry \& Environmental Science, University of Agricultural

Sciences, GKVK Campus, Bengaluru, Karnataka 560065, India

${ }^{3}$ \# 11, Temple Road, Jayalakshmipuram, Mysuru, Karnataka 570012, India

${ }^{1}$ sampathsringeri@yahoo.com (corresponding author), ${ }^{2}$ ansringesh@gmail.com,

${ }^{3}$ shubhadutt21@gmail.com, ${ }^{4}$ hasriprakash@gmail.com

During the botanical explorations in Kunthi Betta near Pandavapura of Mandya District (Karnataka State), the authors came across an interesting species of Ficus of the family Moraceae growing in rock crevices. On careful examination and extended search, this turned out to be Ficus dalhousiae Miq. (Image 1). Interestingly, it is a species endemic to peninsular India (Ahmedullah \& Nayar 1986) and a very rare species (Sukumaran et al. 2008). Miquel (1847) first described this species as Urostigma dalhousiae based on Wight's collection from India and later (1867) he renamed it as Ficus dalhousiae. Subsequently, King (1888), Hooker (1890), Brandis (1906) and Gamble (1928) recorded this species from the Nilgiri Mountains in the altitudinal range of 605-1,370 $\mathrm{m}$. This species has been reported from many parts of Kerala (Bourdillon 1908; Corner 1965; Nayar et al. 2006; Sasidharan, 2006), Tamil Nadu (Henry et al. 1987; Sukuraman et al. 2008) and Andhra Pradesh (Pullaiah \& Rani 1999). So far, this species has not been reported from Karnataka. Therefore, the present sighting in
Kunthi Betta near Pandavapura forms a new distribution record for Karnataka (Image 2). It is briefly described here with phenological data, its distribution, a specimen examined and notes for a better understanding of the species. A voucher specimen (Image 3) has been deposited by the authors (KBF 1001) in the herbarium of the Department of Studies in Botany (MGM), University of Mysore, Manasagangotri, Mysuru.

\section{Ficus dalhousiae Miq.}

in Ann. Mus. Bot. Lugduno-Batavi. 3: 285. 1867; Hooker in Fl. Brit. India. 5: 499. 1890; Gamble in FPM. Repr. ed. 3:1364. 1998. Urostigma dalhousiae Miq. in London J. Bot. 6:571. 1847.

Specimen examined: KBF-1001, 01.xi.2008, hill top of Kunthi Betta $\left(12.5061^{\circ} \mathrm{N} \& 76.6925^{\circ} \mathrm{E}\right)$, near Pandavapura (Mandya District), Karnataka (India), coll. K.K. Sampath Kumara, A.N. Sringeswara, K.B. Sadananda. We observed only a single tree of $F$. dalhousiae in the study area.

Description: A small spreading tree; young branches softly pubescent. Leaves ovate-elliptic to broadly ovate, white pubescent below; apex shortly acuminate; base more or less deeply cordate, up to $30 \mathrm{~cm}$ long and $20 \mathrm{~cm}$ broad; primary nerves $10-14$ pairs, prominent below; petioles up to $10 \mathrm{~cm}$ long. Receptacles in pairs, shortly peduncled, obovoid, pubescent, about $1.5 \mathrm{~cm}$ in diameter, with three apical scales and three bifid basal bracts.

Habitat: Rocky hill top of dry deciduous forest.

Phenology: September-February.

Distribution: Peninsular India: Andhra Pradesh, Tamil

DOI: http://dx.doi.org/10.11609/JoTT.o3012.4808-10

Editor: N.P. Balakrishnan, Retd. Botanical Survey of India, Coimbatore, India.

Date of publication: 26 September 2013 (online \& print)

Manuscript details: Ms \# 03012 | Received 20 November 2011 | Final received 02 July 2013 | Finally accepted 18 August 2013

Citation: Kumara, K.K.S., A.N. Sringeswara, K.B. Sadananda \& H.S. Prakash (2013). New distribution record of the endemic and rare Ficus dalhousiae Miq. (Moraceae). Journal of Threatened Taxa 5(13): 4808-4810; http://dx.doi.org/10.11609/JoTT.03012.4808-10

Copyright: @ Kumara et al. 2013. Creative Commons Attribution 3.0 Unported License. JoTT allows unrestricted use of this article in any medium, reproduction and distribution by providing adequate credit to the authors and the source of publication.

Funding: Self funded.

Competing Interest: The authors declare no competing interests.

Acknowledgements: We thank Dr. G.V.S. Murthy and Sri. J.V. Sudhakar (BSI, Southern circle, Coimbatore) for their help in plant identification. Thanks are also due to Sri. A. Shivaprakash for photographs of the plant. 


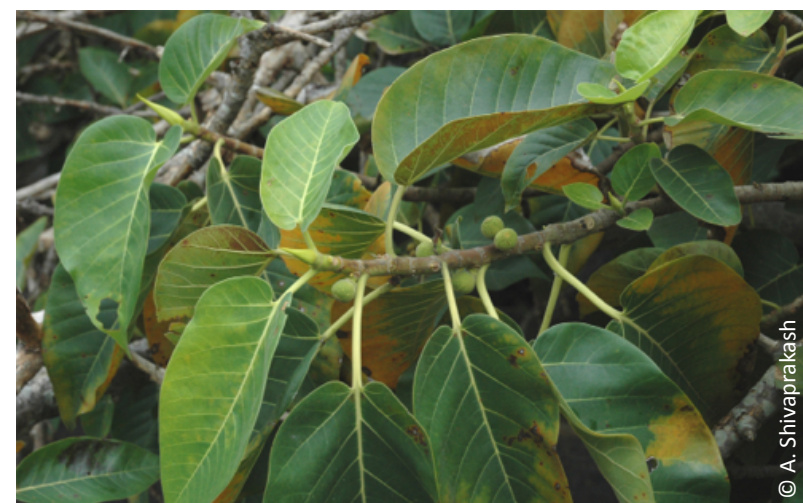

Image 1. Ficus dalhousiae Miq. tree branches bearing receptacles

Nadu, Kerala and Karnataka. Endemic and very rare.

Discussion: The sighting of only one tree of $F$. dalhousiae in the study area indicates its rarity. We have also sighted a few trees of this species growing on the rocky hill tops of Savanadurga (Ramanagaram District of Karnataka) and Siddara Betta (Tumkur District of Karnataka). Wherever it grows, its population size is very small and probably that is the reason for its inclusion

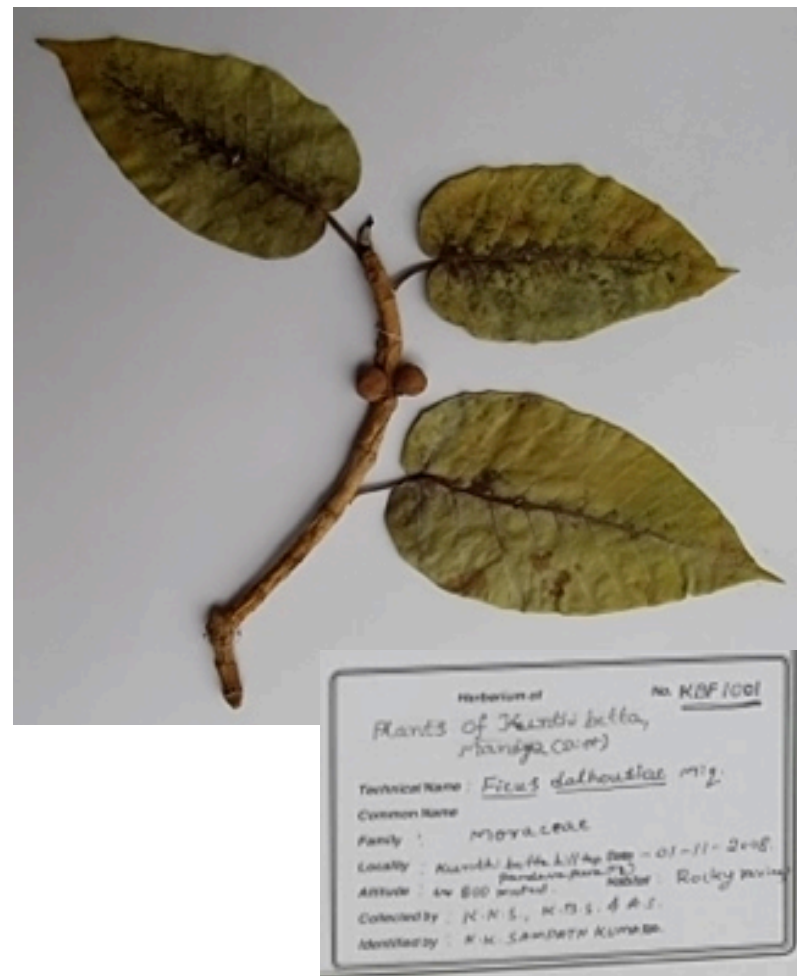

Image 3. Ficus dalhousiae Miq. herbarium specimen

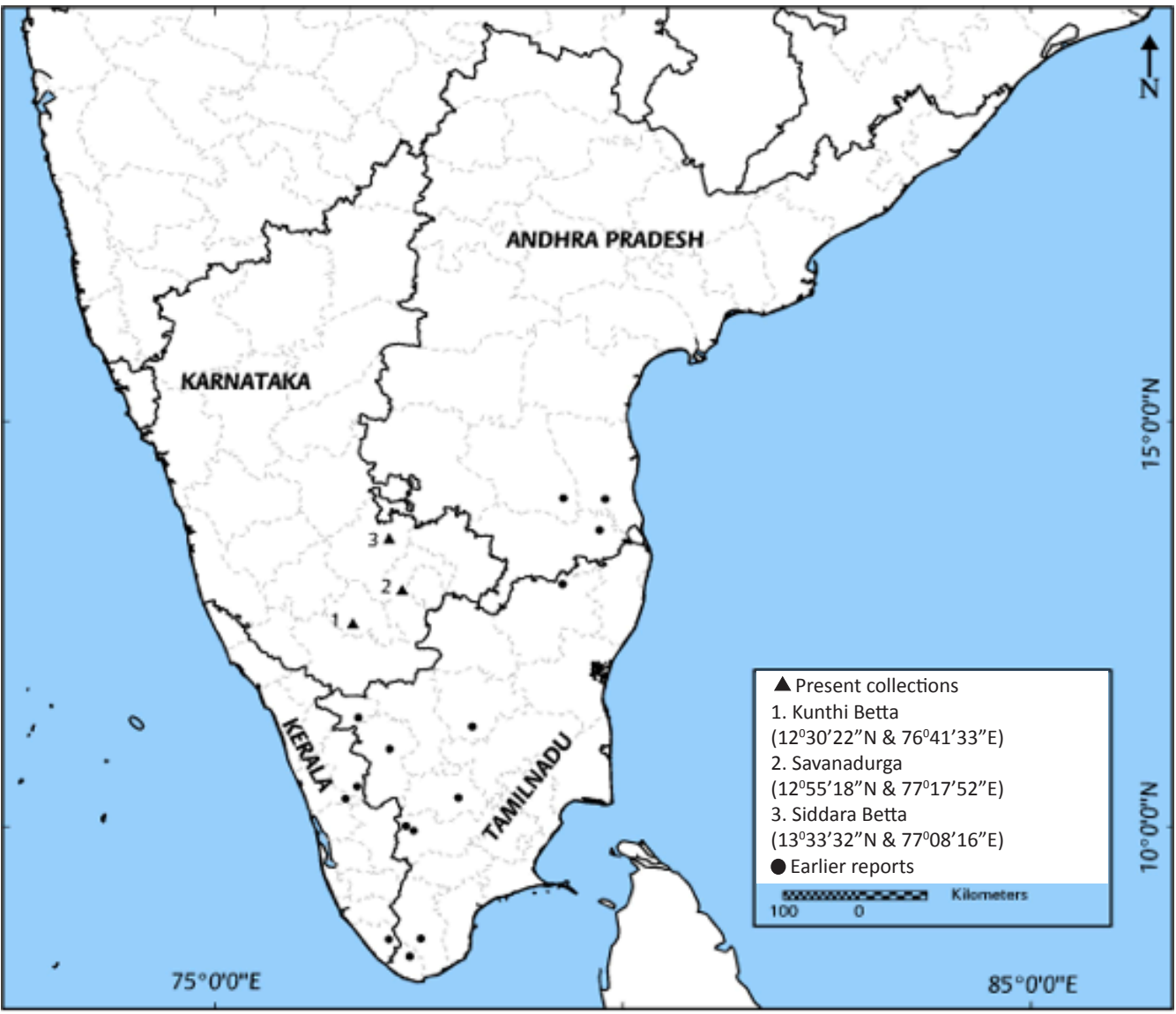

Image 2. Map showing the distribution of Ficus dalhousiae Miq. 
under the very rare category in the threatened plants list (Sukumaran et al. 2008). Future studies should address reasons for its endemism and factors affecting the abundant growth of this plant's populations. That may help us to conserve this very rare species.

\section{REFERENCES}

Ahmedullah, M. \& M.P. Nayar (1986). Endemic Plants of Indian Region. Botanical Survey of India, Calcutta, 261pp.

Bourdillon, T.E. (1908). The Forest Trees of Travancore. The government Press, Trivandrum, 456pp.

Brandis, D. (1906). Indian Trees: An Account of Trees, Shrubs, Woody Climbers, Bamboos, and Palms Indigenous or Commonly Cultivated in The British Indian Empire. Archibald Constable \& Co. Ltd., London. $601 \mathrm{pp}$.

Corner, E.J.H. (1965). Checklist of Ficus in Asia and Australia with keys to identification. The Gard. Bull. Singapore, 21: 1-186.

Gamble, J.S. (1928). Flora of the Presidency of Madras. University of California, London, $577 p p+x$.
Henry, A.N., G.R. Kumar \& V. Chitra (1987). Flora of Tamil Nadu, India, Ser. I: Analysis, 2. Botanical Survey of India, Coimbatore, 613pp

Hooker, J. D. (1890). Flora of British India. L. Reeve \& Co. Ltd., Ashford, Kent, 5: 499.

King, G. (1888). The species of the Ficus of the Indo-Malayan and Chinese countries. Annals of the Royal Botanic Garden, Calcutta 1: t.11.

Miquel, F.A.W. (1847). Prodromus Monographiae Ficuum. The London Journal of Botany 6: 571.

Miquel, F.A.W. (1867). Annotationes de Ficus speciebus. Annales Musei Botanici Lugduno-Batavi, Amsterdam 3: 285.

Nayar, T.S., A.R. Beegam, N. Mohanan \& G. Rajkumar (2006). Flowering plants of Kerala - A Handbook. Tropical Botanical Garden Research Institute, Thiruvananthapuram, Kerala, 434pp.

Pullaiah, T. \& S.S. Rani (1999). Trees of Andhra Pradesh, India. Regency Publications, New Delhi, 426pp.

Sasidharan, N. (2006). Illustrated manual on tree flora of Kerala supplemented with computer-aided identification. Kerala Forest Research Institute, Peechi, Kerala.

Sukumaran, S., S. Jeeva, A.D.S. Raj \& D. Kannan (2008). Floristic Diversity, Conservation Status and Economic Value of Miniature Sacred Groves in Kanyakumari District, Tamil Nadu, Southern Peninsular India. Turkish Journal of Botany 32: 196. 